\title{
Grand Challenges in Studying Comparative Governance
}

\author{
Antoaneta L. Dimitrova* \\ Institute of Security and Global Affairs, Faculty of Governance and Global Affairs, Leiden University, The Hague, Netherlands
}

Keywords: governance, globalization, modes of governance, anthroposcene, power, asymmetry, climate change, geoengineering

Research in the various forms and manifestations of "governance" has been holding central stage in social sciences since the early 2000s. New modes of governance (Kohler-Koch and Rittberger, 2006) have been investigated in numerous research projects and even, in the framework of entire, country-wide research programmes (Van Kersbergen and Van Waarden, 2004). Research in governance has aimed to capture aspects of governing that are non-hierarchical, not (only) state based, involving multiple arenas and diverse actors. In this sense, governance arose as a term to denote steering exchanges and instances of rule creation which were not centered (exclusively) on government. However, as "governance" gained currency, it has been increasingly used interchangeably with government, which arguably limits its conceptual power (Offe, 2009).

To complicate matters, as Van Kersbergen and Van Waarden (2004) have noted, governance has been defined differently by different disciplines. Diversity in disciplinary approaches can be a source of confusion, but can equally lead to productive inter- and trans disciplinary exchanges to capture the many facets of governance.

Arguably, today more than ever, different forms of governance can be best understood by looking through different disciplinary lenses and perspectives. Anthropologists, for example, are able to deliver insights on how governance in non-Western societies is changed and challenged by responses to technological change, such as the wide-spread use of mobile phones in Africa (e.g., Brinkman et al., 2017). While governance of markets and monetary systems may be the domain of economists, responses to economic decisions and monetary arrangements that change economic governance can only be understood with the help of political scientists and historians (e.g., Kleider and Stoeckel, 2019). Efforts to create the much needed cross border governance of climate change policies may be devised by politicians, but they need to be analyzed by policy scholars, political scientists, and economists, while environmental specialists are needed to understand and analyse the governance of biodiversity. Political psychologists deliver new insights, often through experiments, on how citizens perceive the international arena and global aspects of governance (e.g., Petersen and Aarøe, 2013), while political scientists can deliberate on policies more attuned to citizen needs (Dryzek, 2016). Research on governance is, and should be, therefore, ideally always interdisciplinary or transdisciplinary, utilizing insights from all relevant disciplines.

The breadth of the concept of governance can also be a weakness. "Governance" has been criticized for the lack of clear definitional boundaries and concept stretching. If we call everything "governance," there would be no possibility for differentiating it from government. The need for clear conceptualization and clarity in situating the concept of governance in relation to key concepts in political science and public administration (concepts such as government, institutions, but also networks) is even more urgent as research on governance proliferates.

Furthermore, we need to employ cleat definitions to be able to integrate research on governance into the body of past literature in political science, public policy, historical sociology, and many other disciplines engaged with studying state-society interactions that steer society. The ideas and findings produced in the past have clear implications for present research and debates on issues that affect all countries and citizens. So while governance is relatively new, insights at different levels of what good government is or how it can be achieved certainly should inform our thinking. 
Thus, the first key challenge in research focusing on governance is:

- Developing conceptualizations that delineate clearly the boundaries of governance as a concept and using it in such a way that the added analytical leverage is manifest.

Even though this is not a new challenge, clearly it remains a serious one. Successful work in conceptualizing governance has often been one that sets out to classify modes of governance by identifying key features or disaggregating complex interactions across borders or over time. It has, for example, resulted in a large body of literature on "multi-level governance," starting with the seminal work on the EU by Marks and Hooghe (Marks et al., 1996; Hooghe and Marks, 2001). Later work has explored various modes of governance in specific settings and with specific characteristics, giving rise to related, yet distinct bodies of literature exploring "governance with adjectives": external governance (Lavenex and Schimmelfennig, 2009), enlargement governance (Dimitrova, 2002), experimentalist governance (Sabel and Zeitlin, 2008, 2012). Another rising subfield of research in public policy and public administration delves into participatory and collaborative governance (Batory and Svensson, 2019).

It can be argued that part of this first challenge is to maintain of the conversation between scholars of governance by using, as much as possible, a unified framework of reference so that we can compare various modes or types of governance across bodies of literature. Some of the aspects that need to be identified by those excited to add another type of governance to our vocabulary are: the actors involved in a "new" mode of governance, the way they are situated or cross between traditional arenas of international, transnational, or local politics, the way they interact and the specific modes of interaction: horizontal or hierarchical, network or regime based. While governance by its very nature involves repeated interactions to steer or mobilize behavior, the duration and frequency of interactions should receive attention and specification as well.

The early literature on governance has been able to break new ground by identifying patterns of involvement of actors in various arenas that have produced specific policy outcomes or contributed to them: often targeting regulation or problem solving. The best known examples stem from the literature on multi-level governance in the European Union (EU) which started from analyzing cohesion policy and showing that interactions did not take place according to patterns expected by then established theories of European integration (Marks et al., 1996; Bache et al., 2016).

A common assumption of work on governance has been that "governance" takes place where government is not present or cannot act to achieve desired results. Yet, as Offe (2009) noted, this has resulted in the policy and expert community often embracing governance as the equivalent to problem solving, thus precluding a critical examination of its weaknesses and the character of the outcomes.

- A second challenge is, therefore, to deliver critical analyses of modes and types of governance that assess their shortcomings and effectiveness, potentially in a comparative perspective, comparing to "traditional" government or to other modes of governance.

Another important aspect of criticism is that when governance is viewed as a depoliticized process it serves to obscure the conflicts of interests and values behind public policy. The emphasis on modes and forms of governance involving multiple actors has also created a blindness to aspects of power asymmetry behind governance processes (Offe, 2009, p. 556-558). Power asymmetry can be inherent in governance patterns which are not, at first glance, hierarchical, such as the EU's enlargement governance (Dimitrova, 2002).

- Researching specific forms of governance and its patterns of interactions that, just like different forms of government, might privilege some actors and disempower or exclude others is the third grant challenge for the thriving research in governance.

As we are currently experiencing a wave of globalization of particular breadth and impact, with economic, environmental, cultural, demographic and health implications, policy makers, and citizens all over the world are seeking for ways to cope with and govern globalization processes. This opens the way for developing research in governance responding to global problems: the governance of crises and governance of responses to climate change.

- A fourth grand challenge is, therefore, the exploration of governance of emerging fields of human activity that aim to cope with the consequences of climate change, technological change, or population movement and exploration of the planet and beyond: governance of geoengineering ${ }^{1}$, governance of artificial intelligence, governance of space exploration.

While these themes may be particularly exciting for a new generation of scholars, we need to address them mindfully of our first and second grand challenge and define clearly how emerging types of governance would be situated within the unified frameworks of reference we strive to maintain. Otherwise, devising new-much needed-forms of governance, may be prone to speculation or lack of critical insights due to insufficient data and future oriented character. Yet innovation can be delivered in scholarship exploring governing the Anthropocene, as shown by the pioneering work by Dryzek on "governing the changing earth system" (Dryzek, 2016, p.937).

Comparative governance, the broad theme of this section, aims to publish exciting work that addresses these grand challenges and identifies, analyses and critically assesses modes of governance across and within national borders. We encourage theory driven and conceptually sophisticated work, but also aim for contributions that capture governance by gathering and systematically analyzing empirical data from all parts of the world. We would particularly welcome research that utilizes new

\footnotetext{
${ }^{1}$ See for example the argument for governance of geoengineering here: cfr.org/blog/world-may-need-geoengineering-and-geoengineering-needs -governance.
} 
ways of gathering data on the complex topic of governance, for example innovative methodological approaches to capturing informal governance, network governance, or global patterns of regulatory governance. Bold and forward looking approaches are welcomed, especially when they strive to bring diverse disciplinary perspectives into play and create evidence based, theory informed models of the new forms of governance in the future.

\section{REFERENCES}

Bache, I., Bartle, I., and Flinders, M. (2016). "Multi-level governance," in Handbook on Theories of Governance. Cheltenham: Edward Elgar Publishing.

Batory, A., and Svensson, S. (2019). The fuzzy concept of collaborative governance: a systematic review of the state of the art. Central Eur. J. Public Policy. 13. doi: 10.2478/cejpp-2019-0008

Brinkman, I., Both, J., and de Bruijn, M. (2017). The mobile phone and society in South Sudan: a critical historical-anthropological approach. J. Afr. Media Stud. 9, 323-337. doi: 10.1386/jams.9.2.323_1

Dimitrova, A. (2002). Enlargement, institution-building and the EU's administrative capacity requirement. West Eur. Polit. 25, 171-190. doi: $10.1080 / 713601647$

Dryzek, J. (2016). Institutions for the anthropocene: governance in a changing earth system. Br. J. Polit. Sci. 46, 937-956. doi: 10.1017/S0007123414000453

Hooghe, L., and Marks, G. W. (2001). Multi-Level Governance and European Integration. Lanham, MD: Rowman \& Littlefield.

Kleider, H., and Stoeckel, F. (2019). The politics of international redistribution: explaining public support for fiscal transfers in the EU'. Eur. J. Polit. Res. 58, 4-29. doi: 10.1111/1475-6765.12268

Kohler-Koch, B., and Rittberger, B. (2006). The 'governance turn' in EU studies. J. Common Market Stud. 44, 27-49. doi: 10.1111/j.1468-5965.2006.00642.x

Lavenex, S., and Schimmelfennig, F. (2009). EU rules beyond EU borders: theorizing external governance in European politics. J. Eur. Public Policy 16, 791-812. doi: 10.1080/13501760903087696

Marks, G., Hooghe, L., and Blank, K. (1996). European integration from the 1980s: State-centric v. multi-level governance. J Common Market Stud. 34, 341-378.

\section{AUTHOR CONTRIBUTIONS}

The author confirms being the sole contributor of this work and has approved it for publication.

\section{ACKNOWLEDGMENTS}

I am grateful for the comments and suggestions of the reviewer.

Offe, C. (2009). Governance as an empty signifier Constellations 16, 550-562. doi: 10.1111/j.1467-8675.2009.00570.x

Petersen, M. B., and Aarøe, L. (2013). Politics in the mind's eye: Imagination as a link between social and political cognition. Am. Polit. Sci. Rev. 107, 275-293. doi: 10.1017/S0003055413000026

Sabel, C. F., and Zeitlin, J. (2008). Learning from difference: the new architecture of experimentalist governance in the EU. Euro. Law J. 14, 271-327.

Sabel, C. F., and Zeitlin, J. (2012). "Experimentalist governance," in The Oxford Handbook of Governance, Vol. 1, 2-4. doi: 10.1093/Oxfordhb/9780199560530.013.0012

Van Kersbergen, K., and Van Waarden, F. (2004). 'Governance' as a bridge between disciplines: cross-disciplinary inspiration regarding shifts in governance and problems of governability, accountability and legitimacy. Eur. J. Polit. Res. 43, 143-171. doi: 10.1111/j.1475-6765.2004. 00149.x

Conflict of Interest: The author declares that the research was conducted in the absence of any commercial or financial relationships that could be construed as a potential conflict of interest.

Copyright (c) 2020 Dimitrova. This is an open-access article distributed under the terms of the Creative Commons Attribution License (CC BY). The use, distribution or reproduction in other forums is permitted, provided the original author(s) and the copyright owner(s) are credited and that the original publication in this journal is cited, in accordance with accepted academic practice. No use, distribution or reproduction is permitted which does not comply with these terms. 